\title{
HOLOCENE EVOLUTION OF THE OUTER LAKE OF HWAJINPO LAGOON ON THE EASTERN COAST OF KOREA; ENVIRONMENTAL CHANGES WITH HOLOCENE SEA-LEVEL FLUCTUATION OF THE EAST SEA (SEA OF JAPAN)
}

\author{
Jong-Gwon Yum ${ }^{1,2} \bullet$ Kang-Min Yu ${ }^{3}$ Keiji Takemura ${ }^{4}$ Toshiro Naruse ${ }^{5}$ Akihisa Kitamura ${ }^{6}$ \\ Hiroyuki Kitagawa ${ }^{7}$ Jong-Chan Kim ${ }^{1}$
}

\begin{abstract}
The evolution of the outer lake of Hwajinpo Lagoon in Korea has been reconstructed using environmental proxies (lithologic, geochemical, and fossil data) with a chronology established using 7 accelerator mass spectrometry (AMS) radiocarbon dates. Grain size, water content, and X-ray analyses from the core of outer coastal lakes (HJ99) were used to reconstruct sedimentary environments by using total organic carbon, $\mathrm{C} / \mathrm{N}, \mathrm{S}$, and $\mathrm{C} / \mathrm{S}$ chemical proxies. Assemblages of mollusc remains also provided paleoenvironmental information. The environmental changes of the outer lake of Hwajinpo Lagoon can be divided into 6 depositional phases. The basin of the Hwajinpo was exposed and underwent a weathering process before the Holocene period. The muddy sand layer on the weathered bedrock indicated an estuarine system about $6000 \mathrm{BP}$. The laminated layer implies that the lagoonal system was anoxic between about 5500-2800 BP. The marl layer implies a relatively oxic lagoonal condition with mollusc presence about $2500 \mathrm{BP}$. The layer of very low sulfur content indicates a freshwater lake system isolated by a sand barrier about $1700 \mathrm{BP}$. Beginning about $1000 \mathrm{BP}$, the river system deposits progress progradation on the marl layer. Two erosional landforms could be related with a high standing sea level span during Holocene. These high-stands are dated at $5700 \mathrm{BP}$ and $2200 \mathrm{BP}$ and are supposed to have formed erosional landforms of about 1.6 amsl and $0.8 \mathrm{amsl}$, respectively. Environmental changes of the outer lake of Hwajinpo Lagoon are considered due mainly to the lake- and sea-level fluctuation during Holocene.
\end{abstract}

\section{INTRODUCTION}

A lagoonal system can be a useful indicator to understand the history of sea-level change because of its high sensitivity with even small variations of sea level (e.g. Howell et al. 1988; Carter et al. 1989; Eitner 1996; Kirk and Lauder 2000; Li et al. 2001). In addition, a number of sedimentary studies on coastal lagoon systems indicate that the origin and geological histories of coastal lagoons are associated with sea-level changes during the Holocene (e.g. Dominguez et al. 1987; Kraft et al. 1981; Selivanov 1996; Morton et al. 2000).

Holocene sea-level changes of the East Sea (Sea of Japan) have been frequently discussed (Korotkii 1985; Okada 1978; Toyoshima 1978; Tokuoka et al. 1990; Selivanov 1996; Ishiga et al. 2000). They are mostly generated from the western coast of the Japanese Islands, which are known as active blocks. It is essential to compare these data with results from a tectonically stable area such as Hwajinpo Lagoon, in order to confirm overall variation in the East Sea area. A few studies have reported the geologic and environmental aspect of the lagoon. Jung and Park (1976) studied bottom sediment distribution of the Hwajinpo; Park and Kim (1981) investigated sand barrier developments; and Yum et al. (2002) determined recent depositional environment of Hwajinpo Lagoon. Sediment facies of the inner lake of Hwajinpo Lagoon were studied by Yum et al. (2003). Nevertheless, age determination was impossible largely due to difficulties in finding the dating material. Lithological and geochemical analyses with reliable age control using the core from the outer lake of Hwajinpo

\footnotetext{
${ }^{1}$ AMS Laboratory, National Center for Inter-University Facilities, Seoul National University, Seoul, 151-742, Korea.

${ }^{2}$ Corresponding author. Email: yums@ieg.or.kr.

${ }^{3}$ Department of Earth System Sciences, College of Sciences, Yonsei University, Seoul, 120-749, Korea.

${ }^{4}$ Beppu Geothermal Research Laboratory, Institute for Geothermal Science, Graduate School of Science, Kyoto University, Beppu, 874-0903, Japan.

${ }^{5}$ Department of Geography, Hyogo University of Teacher Education, Hyogo, 673-1494, Japan.

${ }^{6}$ Institute of Geosciences, Faculty of Science, Shizuoka University, Shizuoka 422-8529, Japan.

${ }^{7}$ Institute for Hydrospheric-Atmospheric Science, Nagoya University, Nagoya 464-8601, Japan.
} 
Lagoon should provide information on the history of the paleoenvironment during the Holocene, and also ascertain sea-level fluctuation.

\section{ENVIRONMENTAL SETTING OF HWAJINPO LAGOON}

Hwajinpo Lagoon $\left(38^{\circ} 27^{\prime} \mathrm{N}, 128^{\circ} 28^{\prime} \mathrm{E}\right)$ is a large lagoon; it is composed of 2 small brackish-water lakes which are connected to each other by a narrow channel (Figure 1). It has an area of $2.4 \mathrm{~km}^{2}$ with a maximum water depth of $3.7 \mathrm{~m}$. The basement rock is comprised of the Gyeonggi Gneiss Complex intruded by the Jurassic Daebo granites (Cho et al. 1998). Normally, the lake level approaches near sea level and the tidal range is less than $50 \mathrm{~cm}$. It is difficult to observe ice covered on the lake because of its salinity. The narrow channel between the inner and outer lake is shallow (less than $0.5 \mathrm{~m}$ water depth) and the outer lake has a narrow inlet to the sea which connects only during the summer rainy season (the monsoon season) or by seawater inflow due to waves in storms.

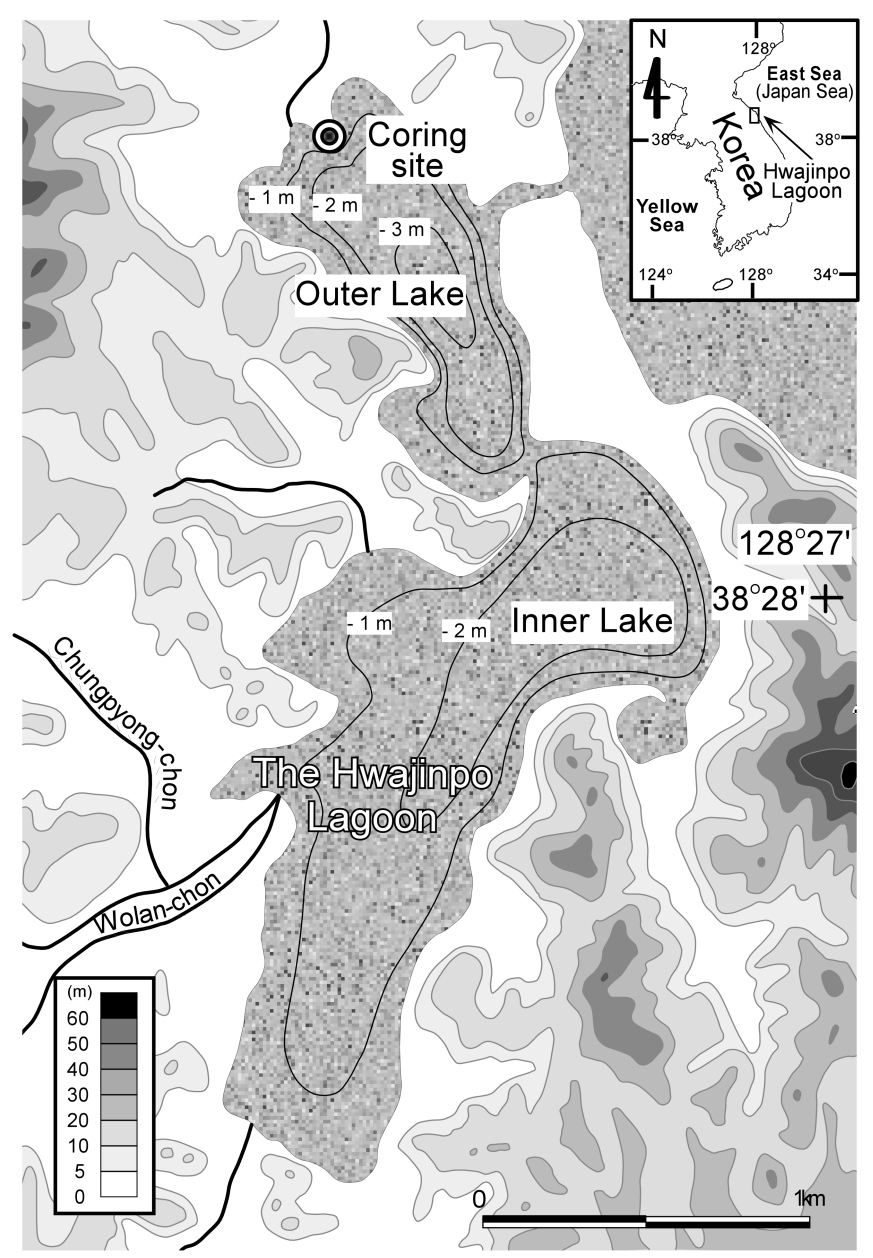

Figure 1 Map showing the location of Hwajinpo Lagoon on the eastern coast of Korea, including the coring site and bathymetry. The largest stream, Chungphyon River, is about $10 \mathrm{~m}$ wide near the river mouth. 
Hwajinpo Lagoon has relatively well-preserved natural sedimentary records compared to other lagoons in Korea (Park and Kim 1981; Yum et al. 2003). Yum et al. (2002) reported that Hwajinpo Lagoon has been brackish over the last $400 \mathrm{yr}$. In addition, a halocline has been developed on each lake and is controlled by the flux of freshwater during the monsoon.

Coastal erosional landforms, such as notches, benches, and sea caves, were developed in granite basement rock. Erosional benches, indicating paleo high water level, were developed at 3 different elevations: present bench; about $0.8 \mathrm{~m}$ above mean sea level (amsl); and about $1.6 \mathrm{~m}$ amsl with a notch. The same levels of 3 platform surfaces were developed in the northern part of the Songjiho Lagoon area, located $25 \mathrm{~km}$ south from the study area. According to Yum (2001), these terraces and erosional geomorphologic features (benches, notches, and sea caves) of the Hwajinpo and Songjiho lagoonal areas are categorized into 3 groups summarized in Figure 2: Group I: $1.5 \sim 2.0 \mathrm{~m}(1.6 \mathrm{~m})$ level; Group II: 0.6 0.9 m (0.8 m) level; and Group III: $0 \mathrm{~cm}$ present mean sea level.

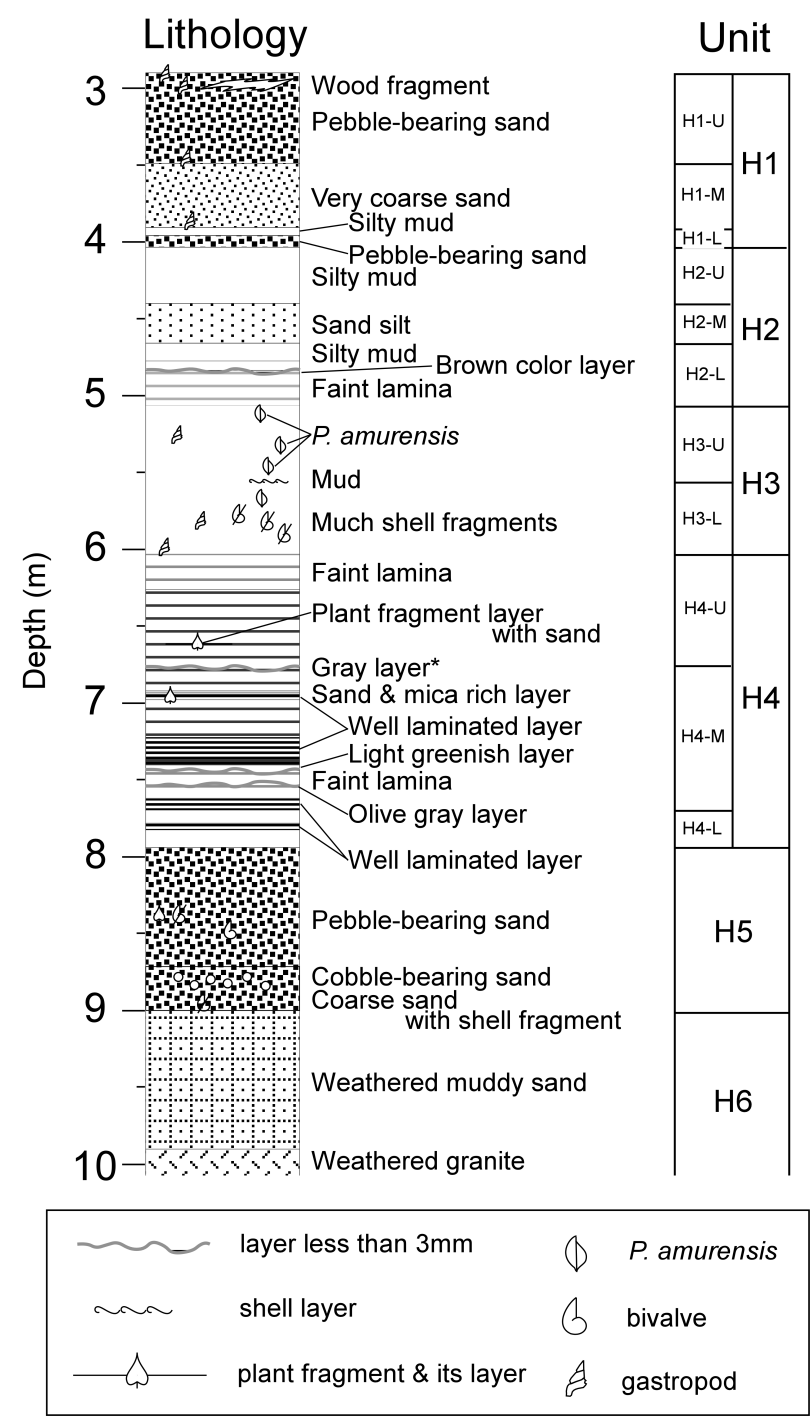

Figure 2 Lithostratigraphic units of the core HJ99 from the outer lake of Hwajinpo Lagoon. Gray layer is determined by X-radiographs. 


\section{METHODS}

Bathymetrical survey on Hwajinpo Lagoon was conducted by using echo-sounding equipment with DGPS (FEG-770). A 10.1-m-long and 5.5-cm-diameter boring core (HJ99) was collected from Hwajinpo Lagoon (Figure 1). The core was sealed in the field site and stored vertically in order to prevent water loss and disturbance. In the laboratory, it was described and photographed while a Xradiograph was carried out with the acryl slab $(1 \times 5 \times 30 \mathrm{~cm})$. It was then subdivided into $2.5-\mathrm{cm}$ slices. After carefully removing the outer rim of core sample, one-fourth of the remaining slices were dried at $70{ }^{\circ} \mathrm{C}$ for $48 \mathrm{hr}$ to calculate sediment water content and for chemical analyses.

Total organic carbon (TOC), total sulfur (TS), and total nitrogen (TN) concentration were measured by an elemental analyzer (EA1108) after removal of carbonates with 1M-HCL (Sampei et al. 1997). Grain size of the sediment was analyzed by a laser-equipped diameter distributor (Mastersizer 2000) after adding enough $10 \% \mathrm{H}_{2} \mathrm{O}_{2}$. Each datum, except water content, was taken at 12.5 -cm intervals in the core. Water content was measured at $2.5-\mathrm{cm}$ intervals. When the core subdivided, all molluscan shells larger than sand size at every $12.5-\mathrm{cm}$ interval, along with the horizontal plane of core, were collected, identified, and counted. We have obtained $7{ }^{14} \mathrm{C}$ ages from wood and plant fragments (Table 1) from the core by the AAA method of Kitagawa (1993) and calibrated the dates using the model of Stuvier et al. (1998).

Table $1{ }^{14} \mathrm{C}$ age dating of the core HJ99 from the outer lake of Hwajinpo Lagoon.

\begin{tabular}{lllc}
\hline Sample & $\begin{array}{l}\text { Depth } \\
(\mathrm{cm})\end{array}$ & Lab code & $\begin{array}{l}{ }^{14} \mathrm{C} \text { age } \\
(\mathrm{BP})\end{array}$ \\
\hline Terrestrial wood fragment & 309 & HK3129 & $60 \pm 30$ \\
Terrestrial wood fragment & 348 & HK3130 & $115 \pm 30$ \\
Terrestrial wood fragment & 408 & HK3132 & $1450 \pm 40$ \\
Terrestrial wood fragment & 610 & HK3135 & $2190 \pm 110$ \\
Terrestrial leaf & 685 & HK3137 & $4050 \pm 60$ \\
Terrestrial plant fragment & 707 & HK3138 & $4240 \pm 80$ \\
Terrestrial wood fragment & 794 & HK2965 & $5580 \pm 50$ \\
\hline
\end{tabular}

\section{RESULTS}

\section{Lithologic Units}

A 10.1-m-thick core (HJ99) of Hwajinpo lagoonal sediment was divided into 6 major lithologic units based on grain size and sedimentary structure observed by logging and X-radiograph. These units have been named the $\mathrm{H} 1, \mathrm{H} 2, \mathrm{H} 3, \mathrm{H} 4, \mathrm{H} 5$, and $\mathrm{H} 6$ units from the top to the bottom (Figure 2). They are subdivided into 11 subunits based on the chemical and biological variations as well as lithologic changes.

\section{Water Contents and Grain Size Analysis}

The variation of water content appears to be related to lithologic changes (Figure 3). The upper part of unit $\mathrm{H} 5$ displays low water content, and unit $\mathrm{H} 4$ shows relatively high water content values compared to the previous unit H5. In subunit H4-L, the values show an increasing trend from $33 \%$ to $60 \%$. The water content values in subunit $\mathrm{H} 4-\mathrm{M}$ displayed a slightly increasing trend, and a slightly decreasing trend in subunit H4-U. A diminishing trend from $61 \%$ to $45 \%$ is shown in the lowermost part of subunit $\mathrm{H} 3-\mathrm{L}$, and the water content shows a constant value in unit $\mathrm{H} 3$ with an average of $44.7 \%$. In all parts of unit $\mathrm{H} 2$, water content shows a slightly declining trend from $44 \%$ to $31 \%$. 
Water content in unit H1, a coarse sand layer, is relatively low. The sand percentage in subunit H4 increased from $2.8 \%$ to $6.6 \%$. Yet, rapidly increasing percentage values of sand at the lower part of unit $\mathrm{H} 3$ show a decreasing trend. In unit $\mathrm{H} 2$, sand percentage increases from $3.5 \%$ to $75 \%$. The mean grain size from the bottom of subunit H4-L to subunit H4-M shows a slight increasing trend, though with some fluctuations which range from $5.4 \phi$ to $6.3 \phi$. The trend of grain size changes to a decreasing pattern from the boundary between $\mathrm{H} 4-\mathrm{M}$ and $\mathrm{H} 4-\mathrm{U}$ to the topmost of subunit $\mathrm{H} 3-\mathrm{U}$, ranging from $5.4 \phi$ to $6.7 \phi$. Then, grain size becomes coarser in unit H2. A general trend of sorting shows an increase, with fluctuations in the whole core which range from $1.7 \phi$ to $2.3 \phi$.

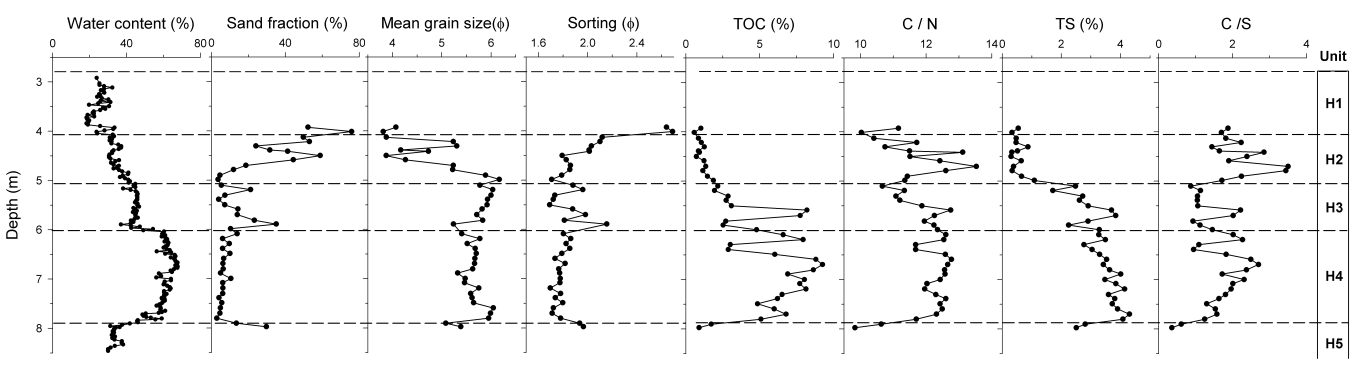

Figure 3 Sedimentology and chemical data from the core of the outer lake of Hwajinpo Lagoon: mean grain size was determined only for muddy units because the high sand contents of $\mathrm{H} 1, \mathrm{H} 5$, and $\mathrm{H} 6$ reflected values at the limit of the analyzer; mean grain size and sorting were calculated by Folk's method (Folk and Ward 1957); TOC (total organic carbon contents), $\mathrm{C} / \mathrm{N}$ (ratio of total organic carbon and nitrogen), TS (total sulfur content), $\mathrm{C} / \mathrm{S}$ (ratio of total organic carbon and sulfur).

\section{TOC, C/N, TS, and C/S}

In subunit H4-L, the TOC content indicates a steep increasing trend, reflecting the lithologic changes from sand to mud (Figure 3). The laminated subunit H4-M demonstrates a higher content of TOC with a slightly increasing trend. In subunits H4-U and H3-L, the value of TOC shows a fluctuation pattern ranging from $2.5 \%$ to $9.2 \%$. Subsequently, the value of TOC is $<2.7 \%$ with a decreasing trend to $0.6 \%$ from subunits $\mathrm{H} 3-\mathrm{U}$ and unit $\mathrm{H} 2$. The $\mathrm{C} / \mathrm{N}$ ratio appears to have no significant variation, through the core ranges between 9.8 and 14.8 with fluctuations. In unit $\mathrm{H} 3-\mathrm{U}$, the $\mathrm{C} / \mathrm{N}$ ratio displays a downward trend.

The steep TS increase in the boundary between $\mathrm{H} 4$ and $\mathrm{H} 5$ units reflects the change of grain size; TS from subunit $\mathrm{H} 4-\mathrm{L}$ to unit $\mathrm{H} 3$ shows a downward trend ranging from $4.1 \%$ to $2.5 \%$ with an average value of $3.3 \%$. Unit $\mathrm{H} 2$ exhibits very low sulfur content of less than $0.8 \%$ with an average value of $0.48 \%$. The $\mathrm{C} / \mathrm{S}$ ratio through the core ranged from 0.8 to 2.7 with an average of 1.7 , except for the subunit H2-L showing a peak shape (maximum value of 3.6).

\section{Mollusca}

Figure 4 shows the stratigraphic distributions and relative abundance of molluscan fossils in the core. Nine species of molluscs are present in core HJ99, including 5 unidentified species. They all are shallow estuarine types of mollusc affected by seawater, especially Potamocorbula amurensis, which is typically a brackish mollusc found in the coastal areas of Korea (Kwon et al. 1993). Unit $\mathrm{H} 5$ contains estuarine molluscs, while units $\mathrm{H} 4$ and $\mathrm{H} 2$ have no molluscs. On the other hand, Unit $\mathrm{H} 3$ contains a large amount of whole molluscs and fragments, including the specific species of brackish mollusc, P. amurensis. Unit H1, containing mainly P. amurensis, presents the recent condition of Hwajinpo Lagoon (Yum et al. 2002) 


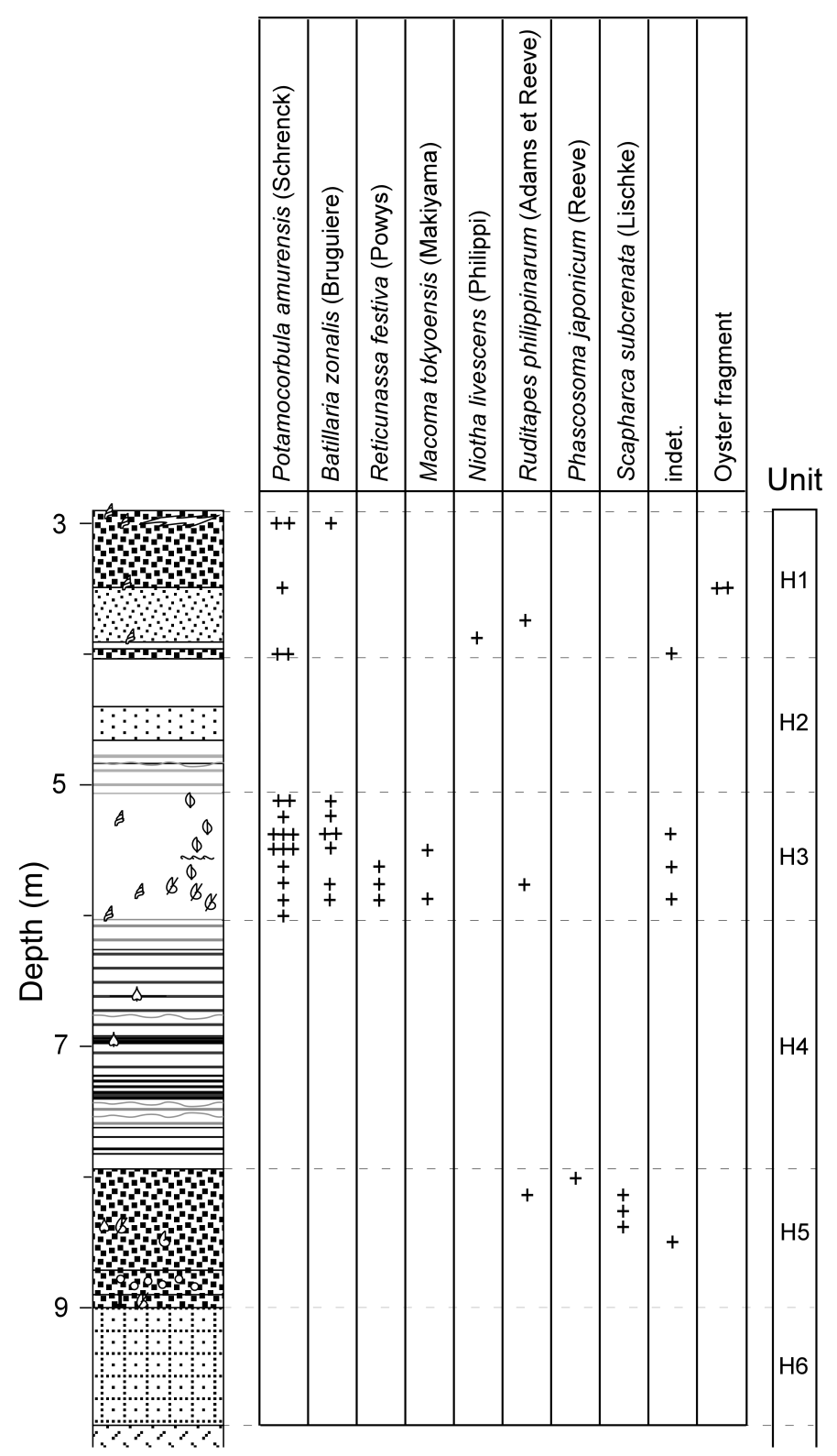

Figure 4 Mollusc abundance in the core HJ99 from Hwajinpo Lagoon; +: 1; $++:$ 2 3; +++: more than 3 individuals.

\section{Sedimentation Rate}

An age-depth model was constructed from 7 AMS ${ }^{14} \mathrm{C}$ dates (Figure 5). The radiocarbon age ranged from $5580 \pm 50 \mathrm{BP}$ at the middle part of unit $\mathrm{H} 5$ to $60 \pm 30 \mathrm{BP}$ in top of unit $\mathrm{H} 1$ (Table 1). A straight line was fit between sections of constant sedimentation to construct this age-depth model. In unit $\mathrm{H} 4$, the sedimentation rate is calculated to $0.69 \mathrm{~mm} / \mathrm{yr}$ by linear interpolation. Units $\mathrm{H} 3$ and $\mathrm{H} 2$ have sedimentation rates of $1.38 \mathrm{~mm} / \mathrm{yr}$. In subunit H1-L, the sedimentation rate is $0.47 \mathrm{~mm} / \mathrm{yr}$, while in subunit $\mathrm{H} 1-\mathrm{U}$ the rate indicates a very fast depositional environment with a sedimentation rate of $7.02 \mathrm{~mm} / \mathrm{yr}$. 


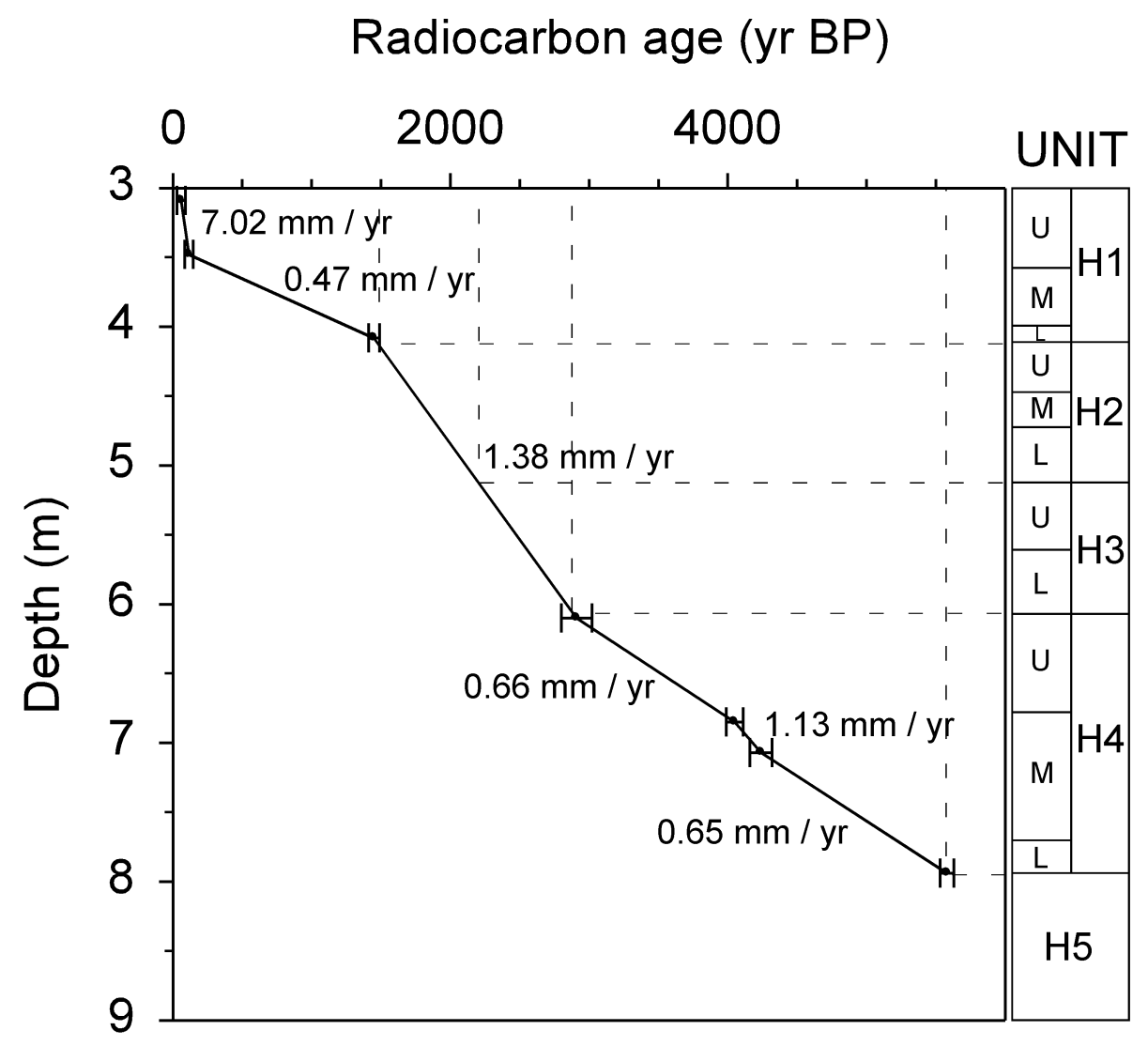

Figure 5 Sedimentation rate in core HJ99 calculated by AMS measurement

\section{DISCUSSION}

\section{Criteria for the Reconstruction of Paleoenvironments in Hwajinpo Lagoon}

Using the several proxy data from the core, reconstruction of the environment during the Holocene is possible with great clarity and in considerable detail. We applied these useful data as environmental proxy and reconstructed the paleoenvironmental history of the outer lake of Hwajinpo Lagoon. Detailed and basic information of events during the Quaternary can often be obtained from the sedimentary records themselves, even though other data, such as chemical or biological evidence, provide useful insights into past environmental conditions. Based on the criteria for reconstruction of paleoenvironments by Yum et al. (2003), environmental changes for the outer lake of Hwajinpo Lagoon were reconstructed as the following 6 depositional environments.

\section{Environmental Changes of the Outer Lake of Hwajinpo Lagoon}

\section{Unit H6 - Weathered Deposit on the Exposed Basement (Before 6800 BP)}

The basement rock of the Hwajinpo Lagoon area is comprised of Gyeonggi Gneiss Complex intruded by Daebo granites that have been the most clastic sources of depositional material to Hwajinpo Lagoon. The time that unit H6 was exposed could be prior to the Last Glacial Maximum period, given that the bottom of unit H5 started deposition after 6800 BP (Yum et al. 2003). 


\section{Unit H5 - Estuarine Deposit (About 6000 BP)}

Unit H5 could be considered tidal inlet sand deposits of estuarine environments during a transgression starting before 5600 BP. The gravel layer in the lower part of this unit was considered a lag deposit which was deposited in the initial time of transgression. Unit H5 displays lower water content related to very poor sorting due to the mixture of sand- and silt-sized grains. The assemblage of estuarine-type molluscs indicates the condition of the outer lake of Hwajinpo Lagoon was an open estuarine system when unit H5 was deposited.

\section{Unit H4 - Stagnant Brackish Lagoonal Deposit (About 5500-2800 BP)}

Yum et al. (2002) have suggested that the difference in the bottom conditions is a consequence of monsoon, which may account for the annual variation of precipitation at Hwajinpo Lagoon area. However, the well-laminated structure in unit $\mathrm{H} 4$ could remain if the bottom water was stable and/ or the absence of bioactivity was absent even after a strong monsoon. The runoff-stagnation model of Howell et al. (1988) by sea-level change explains the development of a well-laminated layer in a brackish lagoonal system. The hypothesis of an isolated basin due to the development of a sand spit in the outer lake of Hwajinpo Lagoon can apply to this model.

Unit H4 shows higher water content values than the previous units H5 and H6. Unit H4 indicates proper sorting and an accordingly stable condition. The sulfur contents are relatively high at the range of about $2.5 \%$, implying a relatively oxygen-poor condition in the bottom sediments. The change of grain size from sand to silt at the boundary between units $\mathrm{H} 5$ and $\mathrm{H} 4$ might be the result of rapid change in the depositional environment. Unit $\mathrm{H} 4$ could be deduced to stagnant bottom and brackish water condition.

The corresponding layer (unit D) of core HJ95 is deposited in the brackish environment, as has been reconstructed from the bases of diatom assemblage (Yum et al. 2003). This unit D layer of HJ95 deposited on the estuarine sand layer dated to about 6000 BP. An overlying layer is a marl deposit with much shell and its fragments, as well as in the unit H4 of HJ99.

\section{Unit H3 - Oxic Condition Marl Deposit (About 2200-2800 BP)}

The upward trend of increasingly finer grain size begins in subunit H4-L due to the rising the lake level and continues up to unit H3. The abundance of shells from unit H3 indicates that the condition of the lake was open and had sufficient oxygen and nutrients, in contrast with the previous unit, according to the oxic condition model of Howell et al. (1998). Mollusca, represented by P. amurensis, indicates a brackish water condition. We see a constant value for water content and susceptibility, and much shell with their fragments occurred in the same range of this unit H3. This should be the consequence of an active bioturbation. The decrease of shell fragments at the top of unit H3 points to the beginning of environmental change from oxygen-rich to oxygen-poor conditions in Hwajinpo Lagoon. The decreasing trend of TS in the top of unit H3 supports this interpretation, i.e., the sulfur supplied from seawater diminished following oxygen-decreasing phenomena by the isolated Hwajinpo lagoonal system.

\section{Unit H2 - Isolated Lake Deposit Influenced by Freshwater (About 1700 BP)}

The low sulfur content of Unit $\mathrm{H} 2$ with its higher value of $\mathrm{C} / \mathrm{S}$ indicates a decrease of seawater influx. The faint lamination in unit H2-L implies a stable and stagnant condition similar to unit H4. This could be due to the decline of sea level, i.e., a sand barrier developed by the rising sea level during the previous stage (unit H3) made the outer lagoon isolated from the sea. Human activity can 
also be taken into account for the development of the sand spit when evaluating these phenomena. However, the overall steady trend of grain size indicates that the barrier was not constructed due to sudden unexpected environmental change, such as a typhoon or flood event. The decrease of sea level is a more reasonable factor for explaining the isolation.

The progressive lowering of the lake level influenced the progradation of the river delta near the coring location. This was followed by the sandy silt layer (subunit H2-M) being deposited at the minimum lake-level stage. The use of land by humans can also indicate another explanation to the sandrich sedimentation; however, TOC and $\mathrm{C} / \mathrm{N}$ ratios do not show the abrupt change that would be expected by human activities. In subunit $\mathrm{H} 2-\mathrm{U}$, the lake level recovered and the grain size became finer than in the previous sandy silt layer.

\section{Unit H1 - Prograding River System (Since 1200 BP)}

In the final stage, the river system deposit consisting of silt and sand was prograding up to the coring location. The presence of $P$. amurensis in this unit indicates brackish water conditions. The value of $\mathrm{C} / \mathrm{N}$ for subunit $\mathrm{H} 1-\mathrm{L}$ indicates a high influx of terrestrial material, while the sedimentation rate of unit H1-U implies that it was deposited only during a few centuries (from $150 \mathrm{BP}$ ), which can possibly be due to land use by humans and the subsequent weathering rate increase.

\section{Evolution Model of the Outer Lakes of Hwajinpo Lagoon}

As a result of our data, we can describe the conceptual evolution model of the outer lake of Hwajinpo Lagoon (shown in Figure 6). The basement rock (Precambrian Gyeonggi Gneiss Complex) was exposed and its surface had been strongly weathered before 6800 BP. Estuarine sediments, including bay-type shells with their fragments, overlie the basement rock. The estuarine deposit on the basement rock was reported in other eastern coasts of Korea. Jo (1980) proposed that the sandy deposits containing molluscs should be related to a rise in sea level during the early Holocene. The age estimated by the depth-age model also suggests a date before $6000 \mathrm{BP}$. Therefore, it is apparent that the outer lake of Hwajinpo Lagoon became an estuarine system during the same phase of sealevel rise.

Subsequently, the decline of sea level caused the Hwajinpo to be isolated in a brackish condition due to frequent influx of seawater. However, the bottom condition was anoxic and could not support living organisms, and a lamination layer developed in the isolated environment (5500-2800 BP).

The subsequent increase of the sea level again allowed the lake bottom to receive a sufficient influx of seawater containing enough oxygen; thus, many molluscs could live in the higher lake-level conditions (2800-2200 BP). By the resulting slight decreases in sea level, Hwajinpo Lagoon became isolated and like a coastal lake, influenced from freshwater influx (about $1700 \mathrm{BP}$ ), or it might have been caused by the role of damming in the development of barriers and/or inlet sand deposit during this high-stand condition of water. Then, with the rising sea level, Hwajinpo Lagoon reached its present condition and the river system was prograding upon the HJ99 coring location.

\section{Sea-Level Fluctuation of the East Sea (Sea of Japan) During the Holocene}

The erosional landform near the study area shows high-stand paleosea and/or lake-level conditions above the present sea level (about $0.8 \mathrm{~m}$ and $1.6 \mathrm{~m} \mathrm{abml}$ ). The AMS age data from $1.6-\mathrm{m}$ terraces indicate that they were formed during the mid-Holocene stage (Yu et al., forthcoming). Also, other previous studies on the sea level of the East Sea showed that there are more than 2 higher-stand conditions above the present sea level during the Holocene (e.g. Ota et al. 1990; Selivanov 1996; 


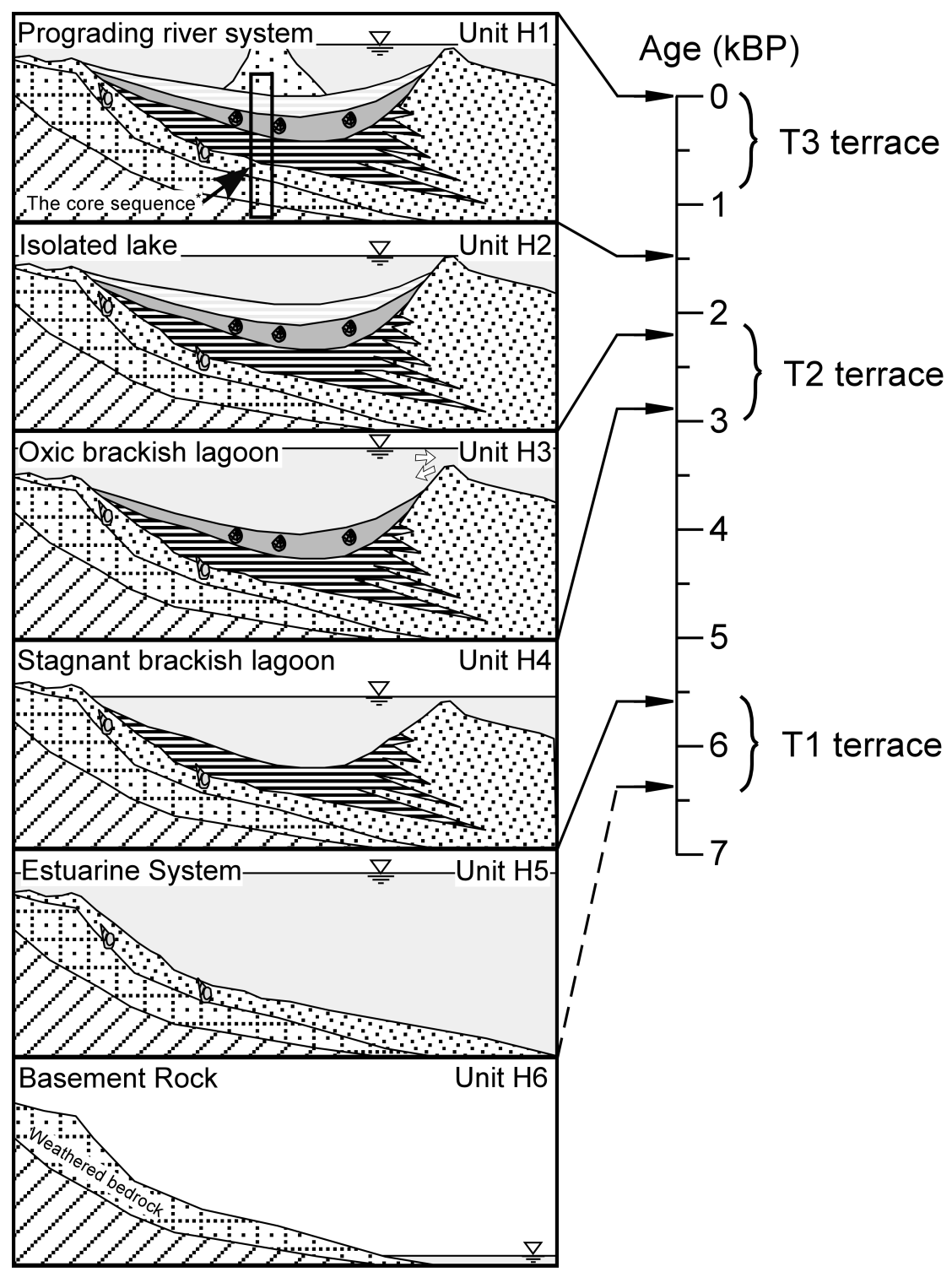

Figure 6 Conceptional evolution model of the outer lake of Hwajinpo Lagoon. The ages are estimated from ${ }^{14} \mathrm{C}$ dating on the hyphothesis of a constant sedimentation rate; the sea-level changes are presented on a relative scale. Core sequence: the upper most part of the core covered with deltaic sand deposits (Unit H1); left side connected to the inner lake and right side connected to the sea side.

Nakamura et al. 2002; Yum 2001). According to Yum's (2001) suggestion, there are 4 high-stand sea levels during the Holocene in the East Sea area, determined by using the changes of sedimentary faces. The oldest high-stand (about $7500 \mathrm{BP}$ ) is reported at $10 \mathrm{~m}$ below the present sea level, and the fact is concordant with the result of Jo (1980). The youngest high-stand (about $300 \mathrm{BP}$ ) is too short a period to form the obvious erosional landform. Therefore, the high-stands aged about $5700 \mathrm{BP}$ and $2200 \mathrm{BP}$ are supposed to have formed erosional landforms of about $1.6 \mathrm{~m}$ and $0.8 \mathrm{~m}$ level, respectively (Figure 6). 


\section{CONCLUSION}

A multidisciplinary approach, involving lithologic and chemical as well as paleontological and geomorphological research, allows for the reconstruction of the paleoenvironment. It enables the reconstruction of evolution and sea-level changes of the outer lake of Hwajinpo Lagoon.

The environmental changes of the outer lake of Hwajinpo Lagoon can be divided into the following 6 different depositional phases: 1) Exposed basement rock (Unit H6; before 6800 BP); 2) Estuarine deposit (Unit H5; about 6000 BP); 3) Stagnant brackish lagoonal deposit (Unit H4: 5500-2800 BP); 4) Oxic condition marl deposit (Unit H3; about $2500 \mathrm{BP}$ ); 5) Isolated lake deposit influenced by freshwater (Unit H2; about 1700 BP); 6) Prograding river system deposit (Unit H1; beginning about 1000 BP.)

\section{ACKNOWLEDGEMENTS}

We are indebted to Professor YJ Lee of Chungbuk National University and Dr JY Kim of the Korea Institute of Geosciences and Mineral Resources for their helpful comments and suggestion. Dr Yum acknowledges work Korea Research Foundation Grant (KRF-2000-042-D00096) for partial financial support.

\section{REFERENCES}

Cater RWG, Forbes DL, Jennings SC, Orford JD, Shaw J, Taylor RB. 1989. Barrier and lagoon coast evolution under differing relative sea-level regimes: examples from Ireland and Nova Scotia. Marine Geology 88: 221-42.

Cho DL, Hong SH, Chwae U, Lee BJ, Choi P. 1998. Geological report of the Goseong-Ganseong sheet (1: 50,000). Daejeon, Korea: Korea Institute of Geology, Mining and Materials. $12 \mathrm{p}$.

Dominguez JML, Martin L, Bittencourt ACSP. 1987. Sea-level history and Quaternary evolution of river mouth-associated, beach-ridge plain along the eastsoutheast Brazilian coast: a summary. In: Nummedal D, Pilkey OH, Howard JP, editors. Sea-Level Fluctuation and Coastal Evolution. Tulsa: Society of Economic Paleontologists and Mineralogists, special publication nr 41. p 115-28.

Folk RL, Ward WC. 1975. Brazos River bar: a study in the significance of grain-size parameters. Journal of Sedimentary Petrology 27:3-26.

Howell MW, Thunell RE, Tappa E, Rio D, Sprovieri R. 1988. Late Neogene laminated and opal-rich facies from the Mediterranean region: geochemical evidence for mechanisms of formation. Palaeogeography, Palaeoclimatology, Palaeoecology 64:265-86.

Ishiga H, Nakamura T, Sampei Y, Tokuoka T, Takayasu K. 2000. Geochemical record of the Holocene Jomon transgression and human activity in coastal lagoon sediments of the San'in district, SW Japan. Global and Planetary Changes 25:223-37.

Jo W. 1980. Holocene sea-level changes on the east coast of Korea Peninsula. Geography Review of Japan 53: 317-28.

Jung WY, Park YA. 1976. Depositional environments of the recent sediments in the Hwajinpo Lake, Gangweondo, Korea. Journal of Oceanological Society of Korea 11:64-70.

Kirk RM, Lauder GA. 2000. Significant coastal lagoon systems in the South Island, New Zealand-coastal processes and lagoon mouth closure. Science for Conservation 146:5-47.

Kitagawa H, Masuzawa T, Nakamura T, Matsumoto E. 1993. A batch preparation method of graphite targets with low background for AMS ${ }^{14} \mathrm{C}$ measurements. Radiocarbon 35(2):295-300.

Korotkii AM. 1985. Quaternary sea-level fluctuations on the northwestern shelf on the Japan Sea. Journal of Coastal Research 1(3):293-8.

Kraft JC, John CJ, Marx PR. 1981. Clastic depositional strata in a transgressive coastal environment: Holocene epoch. Northeastern Geology 3:268-77.

Kwon OK, Park SM, Lee JS. 1993. Coloured Shells of Korea. Seoul, Korea: Academy Publishing. 446 p.

Li CX, Hang JQ, Fan DD, Deng B. 2001. Holocene regression and the tidal radial sand ridge system formation in the Jiangsu coastal zone, east China. Marine Geology 173:97-120.

Morton RA, Ward GH, White WA. 2000. Rates of sediment supply and sea-level rise in a large coastal lagoon. Marine Geology 167:261-84.

Nakamura T, Tokuoka T, Onishi I, Sampei Y, Takayasu K, Takehiro F, Ege K, Nishio K, Watanabe M. 1996. Holocene environmental changes and lowland historic sites in eastern part of the Shimane prefecture. LAGUNA 3:9-11.

Okada A. 1978. Sea-level change and geomorphic development since the last glacial age in the Wakasa Bay region central west of the Japan Sea coast. Geographical 
Review of Japan 51(2):131-46.

Ota Y, Umitsu M, Matsushima Y. 1990. Recent Japanese research on relative sea-level changes in the Holocene, and related problems - review of studies between 1980-1988. The Quaternary Research (Japan) 29(1):31-48.

Park BK, Kim WH. 1981. The depositional environments of lagoons in the east coast of Korea. Journal of Geological Society of Korea 17:241-9.

Sampei Y, Matsumoto E, Tokuoka T, Inoue D. 1997. Changes in accumulation rate of organic carbon during the last 8,000 years in sediments of Nakaumi Lagoon. Japanese Marine Chemistry 58:39-50.

Selivanov AO. 1996. Morphological changes on Russian coasts under rapid sea-level changes: examples from the Holocene history and implications for future. Journal of Coastal Research12(4):823-30.

Stuiver M, Reimer PJ, Bard E, Beck JW, Burr GS, Hughen KA, Kromer B, McCormac G, van der Plicht J, Spurk M. 1998. INTCAL98 radiocarbon age calibration, 24,000-0 cal BP. Radiocarbon 40(3):1041-83.

Tokuoka T, Onish I, Takayasu K, Mitunashi T. 1990. Natural history and environmental changes of Lakes
Nakaumi and Shinji. Memoir of Geological Society of Japan 36:15-34.

Toyoshima Y. 1978. Postglacial sea-level change along San'in District, Japan. Geographical Review of Japan 51(2):147-57.

Yu KM, Takemura K, Yum JG, Naruse T, Nakanish T, Kim HY. Forthcoming. Elevation of two Holocene sea-level high-stands as recorded by terraces and erosional landforms in the Songiho area, East Sea (Sea of Japan). Marine Geology.

Yum JG. 2001. Late Quaternary environmental changes of the Hwajinpo and Songjiho Lagoons on the eastern coast of Korea [PhD dissertation]. Yonsei, Korea: Yonsei University. $145 \mathrm{p}$.

Yum JG, Sampei T. Tokuoka T, Nakamura T, Yu KM. 2002. Depositional environmental change during the last 400 years in Hwajinpo Lagoon on the eastern coast of Korea. Journal of Geological Society of Korea 38:21-32.

Yum JG, Takemura K, Tokuoka T, Yu KM. 2003. Holocene environmental changes of Hwajinpo Lagoon on the eastern coast of Korea. Journal of Paleolimnology 29:155-66. 